\title{
The Extent and Drivers of Deforestation and Forest Degradation in Masito-Ugalla Ecosystem, Kigoma Region, Tanzania
}

\author{
John E. Makunga ${ }^{1 *}$, Salome B. Misana ${ }^{2}$ \\ ${ }^{1}$ Pasiansi Wildlife Training Institute, Mwanza, Tanzania \\ ${ }^{2}$ Department of Geography, University of Dar es Salaam, Dar es Salaam, Tanzania \\ Email: *jmakunga1@gmail.com, *makungaj2007@yahoo.com
}

How to cite this paper: Makunga, J. E., \& Misana, S. B. (2017). The Extent and Drivers of Deforestation and Forest Degradation in Masito-Ugalla Ecosystem, Kigoma Region, Tanzania. Open Journal of Forestry, 7, 285-305.

https://doi.org/10.4236/ojf.2017.72018

Received: March 4, 2017

Accepted: April 24, 2017

Published: April 27, 2017

Copyright ( 2017 by authors and Scientific Research Publishing Inc. This work is licensed under the Creative Commons Attribution International License (CC BY 4.0).

http://creativecommons.org/licenses/by/4.0/

\begin{abstract}
Deforestation and forest degradation has been observed to be rampant in Masito-Ugalla ecosystem, Kigoma Region, western part of Tanzania. This paper therefore, intended to assess the extent of deforestation and forest degradation in the area, and to determine their causes. A total of 101 respondents were considered as the sample size for this study. The methods used for data collection were household questionnaire interviews, in-depth interviews, focus group discussions, analysis of satellite images and direct observation. The findings indicated that deforestation was occurring in the study area. Satellite data revealed diminished closed woodland, bushed grassland, forest and thickets between 1990 and 2014. On the contrary, settlement area, cultivated land and open woodland had increased during the same time frame. Proximate factors causing deforestation and forest degradation included agricultural expansion, wood extraction and expansion of settlement area. Underlying factors included population growth, poverty, poor levels of education, lack of employment, corruption and embezzlement of public funds by politicians and senior government officials; and high demand for fuel-wood. Biophysical drivers like incidences of unplanned wildfires and socio trigger events notably civil strife were also important. In order to minimize the problem and based on the factors augmenting deforestation and forest degradation in the MasitoUgalla ecosystem and their coupled negative consequences, effective environmental conservation education, increased patrols, effective law enforcement and provision of alternative energy sources are necessary.
\end{abstract}

\section{Keywords}

Deforestation, Forest Degradation, Drivers of Deforestation, Masito-Ugalla Ecosystem 


\section{Introduction}

Although forests cover around $30 \%$ of the Earth's land surface, they are getting lost at an alarming rate (FAO, 2011). Ecologically, forest ecosystems contribute to the protection of watersheds. Forests are key elements in the regulation of hydrological cycles, climate and the reduction of atmospheric pollution and they play an essential role in the global carbon cycle (FAO, 2011). After oceans, forests are the world's largest storehouses of carbon and they provide ecosystem services that are important to human wellbeing (FAO, 2010). These services include absorption of harmful greenhouse gasses that produce climate change. According to WWF (2016), tropical forests alone store a quarter of a trillion tons of carbon in above and below ground biomass. They also provide clean water for drinking, bathing, and other household needs; protect watersheds and reduce or slow the amount of erosion and chemicals that reach waterways; provide food and medicine; act as a buffer in natural disasters like flood and rainfalls as well as provide habitat to more than half of the world's land-based species (WWF, 2016).

Regardless of such immense importance, forests have continued to be degraded and severely depleted. While deforestation is regarded by Hosonuma et al. (2012) as the complete removal of trees and conversion of forests into other land uses, forest degradation involves a change process that negatively affects the characteristics of a forest such that the value and production of its goods and services decline (FAO, 2009). This change process is caused by disturbance (although not all disturbance causes degradation), which may vary in extent, severity, quality, origin and frequency. Disturbance may be natural (e.g. that caused by fire, storm or drought), human-induced (e.g. through harvesting, road construction, shifting cultivation, hunting or grazing) or a combination of the two (FAO, 2009). A degraded forest is a secondary forest that had lost, through human activities, the structure, function, species composition or productivity normally associated with a natural forest type expected on that site UNEP, 2001).

High rates of deforestation have been experienced globally particularly in tropical areas. FAO (2016), for example, reports of a net annual loss of forest of about 7 million hectares between 2000 and 2010 and a decline of forest by 129 million hectares between 1990 and 2010. Such deforestation was reported by FAO (2010) to have been highest in South America, central West Africa, and South and Southeast Asia, with 13 million hectares of global forest lost each year. In contrast, Africa was facing a huge deforestation problem, with the rate of deforestation being higher than in any other continent (Johnson \& Chenje, 2008). Accordingly, of the ten countries in the world with the largest annual net loss of forested area, six were in Africa. On the other hand, Pickering \& Owen (1997) reported that in Europe, widespread deforestation took place from the $11^{\text {th }}$ century as lands were cleared for use as fuel and settled agriculture, thus in 200 years the forests of central Europe were almost entirely depleted.

Empirical evidence reveals that a combination of factors and not a single factor are responsible for the high rates of deforestation that have been experienced 
globally particularly in developing countries (Hosonuma et al., 2012; Geist \& Lambin, 2002; Sitarz, 1994). These include inappropriate land tenure systems, agricultural expansion, e infrastructure expansion and increasing demand for forest products. For example, felling of trees for domestic and agricultural fuel-wood, charcoal, building poles and indiscriminate bush clearing and bush fires for different reasons were reported by Reed (1996) and Misana \& Nyaki (1993) to be causes of deforestation in parts of Africa. Charcoal making, a commercial activity, which in most countries is largely unregulated and outside government controls, has also been reported to be an important cause of deforestation, with its effects largely seen close to cities (Timberlake, 1991).

Forests in Tanzania were being lost at a very high rate of 412,000 hectares per year out of a total forest estate of around 35 million hectares (TFWG, 2009). Although forest loss and degradation were occurring inside Forest Reserves, deforestation was particularly rapid and widespread outside reserved forests (TFWG, 2009), including the Masito-Ugalla ecosystem (MUE). According to URT (2014) the Masito-Ugalla ecosystem is potential as a catchment area for Lake Tanganyika, which serves as an irreplaceable source of clean water, transportation and economic opportunities for an estimated 10 million people in its four riparian countries (Tanzania, Democratic Republic of Congo, Burundi and Zambia). The major challenge facing Lake Tanganyika (URT, 2014) is environmental degradation caused mainly by human induced activities, which pose serious threats to the biodiversity and sustainable use of natural resources in the Lake Tanganyika basin.

Analysis of the deforestation situation in Masito-Ugalla ecosystem was thus, vital to help improve appreciation of the role of rural communities as potential guardians in the management of forest resource to avoid deforestation and forest degradation. The study therefore, had two major objectives: to assess the extent of deforestation and forest degradation, and to determine the causes of such deforestation and forest degradation in the study area. The study examined the drivers of deforestation and forest degradation focusing on both the proximate (direct) and underlying (indirect) causes (Geist \& Lambin, 2002; Hosonuma et al., 2012).

\section{Materials and Methods}

\subsection{The Study Area}

This research was conducted in Ilagala, Karago and Kirando villages, located within the Masito-Ugalla Ecosystem in Uvinza District along the shoreline of Lake Tanganyika (Figure 1). Svoboda, and McNamara (2009) revealed that the MUE is located near the western edge of the East African Rift Valley and Lake Tanganyika, in Western Tanzania and lies between grid reference 138,000E and $278,000 \mathrm{E}$ and between $9,260,000 \mathrm{~N}$ and $9,400,000 \mathrm{~N}$. The ecosystem is surrounded by nine wards, out of which, Ilagala, Sunuka, Sigunga, Mganza, Uvinza and Nguruka are in Uvinza District, Mishamo and Mpanda ndogo wards in Mpanda District and Usinge in Kaliua District, Tabora Region. MUE covers an extensive 


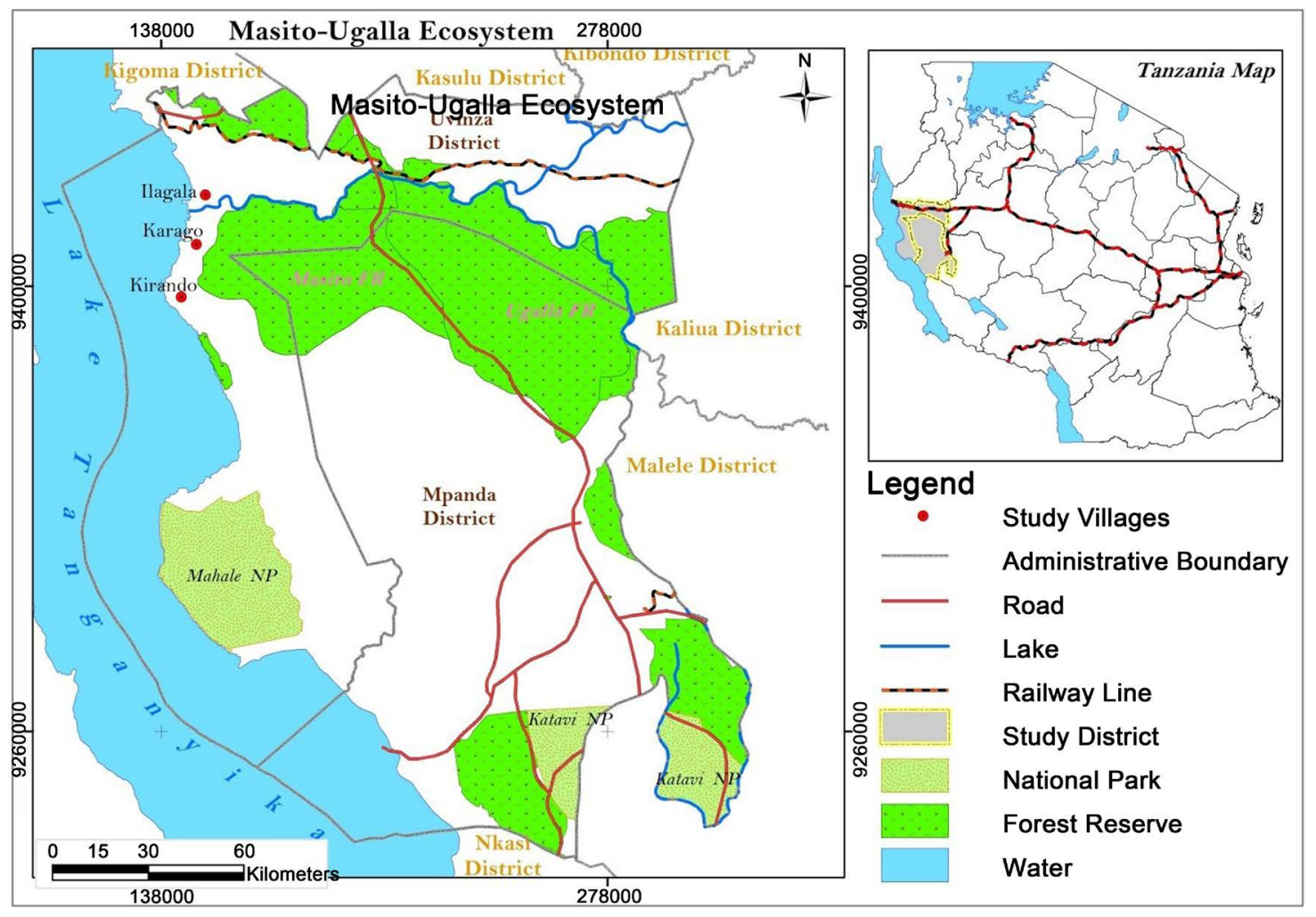

Source: IRA Lab, University of Dar es Salaam (2014).

Figure 1. Location of the study villages in Uvinza District.

forested landscape of $10,827 \mathrm{~km}^{2}$ under different management and ownership regimes (Deloitte, 2012; CIFOR, 2014). Two types of native forest predominate in the area; these are the miombo woodland dominated by Brachystegia species and the lowland rain forest in the valley bottoms (URT, 2014). In addition to woodlands, a large proportion of the region is covered by grasslands (URT, 2014).

\subsection{Data Collection Methods}

A triangulation of methods was used in this study to collect both quantitative and qualitative data. The methods used included remote sensing techniques and geographical information systems (GIS), household questionnaire interviews, in-depth interviews of key informants, focus group discussions and field observations. These methods are described below:

\subsubsection{Remote Sensing and GIS}

Land cover and land use change detection in the forests of Masito and Ugalla, Uvinza and Mpanda Districts were analyzed based on the interpretation of satellite images. Landsat Thematic Mapper ${ }^{\text {mox }}$ for 1990 and Landsat Enhanced Thematic Mapper Plus (ETM+) for 2000 and 2014 were used to extract spatial and temporal land cover and use data. Basically, the study intended to detect land cover changes for every 10 years, from 1990 to 2010. However, it was found interesting to include four extra years from 2010 in order to investigate the effectiveness of the REDD+ project, which lasted for three years from January 2010 to 
December 2013. It was therefore, logical to detect such change using the 2014 Landsat image, since it was the same year in which this study was conducted.

Before analysis of the data, image processing, classification and interpretation were done. Image processing (Vicente-Serrano, 2008) was done by undertaking radiometric and geometric correction. Radiometric correction was employed to make the analyzed images to be recognizable and also avoid the obtained results being invalid (i.e. to reduce the influence of inconsistencies in image brightness values that may limit an ability to interpret). Rocchini \& Rita (2005) found that since all metrics calculated on a landscape (from area coverage by vegetation classes to patches shape and size) are sensible to geometric distortions, thus, the geometric correction of aerial photos is due to allow a realistic multi-temporal study. The process enhances and improves the quality of images for better data extraction. Geometric correction was also employed to remove internal and external distortions in order to identify the location of each pixel on the earth by overlaying with other reference data such as topographical maps (Baboo \& Devi, 2011). The processing activities were done using ERDAS IMAGINE V11. Before image classification, image interpretation was done by identifying all the land cover and use types based on pattern, colour, shape, size, texture and association (Caelli \& Reye, 1993). Image classification was done (Table 1) using supervised

Table 1. Land cover types obtained after image classification.

\begin{tabular}{|c|c|c|}
\hline Id & Class Name & Description \\
\hline 1 & Closed Woodland & $\begin{array}{l}\text { Land dominated by closed trees }(>65 \%) \text {, shrubs and herbaceous plants may be present but are closed to absent } \\
(>65 \%)\end{array}$ \\
\hline 2 & Cultivated Land & $\begin{array}{l}\text { An area characterized by herbaceous vegetation that has been planted or is intensively managed for the } \\
\text { production of food, feed, or fiber; or is maintained in developed settings for specific purposes. Herbaceous } \\
\text { vegetation accounts for } 75 \text { - } 100 \text { percent of the cover. }\end{array}$ \\
\hline 3 & Dense Bushland & $\begin{array}{l}\text { The land in which trees and herbaceous plants may be present, but are closed to absent, while shrubs are } \\
\text { dominant and closed }\end{array}$ \\
\hline 4 & Bushed Grassland & An area characterized by shrubs and grasses. Trees and herbaceous may be present, but are closed to absent \\
\hline 5 & Forest & $\begin{array}{l}\text { The plant life form dominated by tree cover, generally greater than } 6 \text { meters tall); tree canopy accounts for } 25 \\
\text { - } 100 \text { percent of the cover. Shrubs and trees may be present }\end{array}$ \\
\hline 6 & Open Grassland & $\begin{array}{l}\text { An area in which grasses are the dominant vegetation and are open }(65 \%-15 \%) \text {, other vegetation such as } \\
\text { trees, shrubs and herbaceous may be present but are sparse to absent }(15 \%-1 \%)\end{array}$ \\
\hline 7 & Open Bushland & Trees and herbaceous plants are closed to absent, shrubs usually form the main layer and are open \\
\hline 8 & Open Land & Any open piece of land that is undeveloped (has no buildings or other built structures) \\
\hline 9 & Open Woodland & $\begin{array}{l}\text { The land in which the dominant vegetation cover is represented by open trees, with herbaceous plants and } \\
\text { shrubs closed to absent. }\end{array}$ \\
\hline 10 & Settlement Area & An area characterized by community of people \\
\hline 11 & Swamp & $\begin{array}{l}\text { A swamp is a wetland that is dominated by woody plants (i.e. shrubs and trees, defined at the height of less } \\
\text { than } 5 \mathrm{~m} \text { or above } 5 \mathrm{~m} \text { respectively) }\end{array}$ \\
\hline 12 & Thicket & $\begin{array}{l}\text { A plant growth form characterized by shrubs, herbaceous plants and trees may be present, but with sparse } \\
\text { cover }(15 \%-1 \%)\end{array}$ \\
\hline 13 & Water & All areas of open water, generally with less than $25 \%$ cover of vegetation/land cover \\
\hline
\end{tabular}

Source: EPA (2007) \& FAO (2007). 
classification method.

\subsubsection{Household Questionnaire Interviews}

Household interviews were conducted using structured questionnaires consisting of both open and closed-ended questions. A pretest was necessary to determine how the questionnaire could be improved to minimize response errors, such as a respondent misinterpreting a question (Bolton, 1993). A total of 101 respondents, one from each household were interviewed. The types of data, which were collected using this method, included demographic data, education, size of households and income. Other data were the extent of deforestation and forest degradation, causes as well as impacts of deforestation.

\subsubsection{In-Depth Interviews}

In-depth interviews were used to gather qualitative data from key informants, who comprised of the Village Chairpersons, Village Executive Officers, Ward Executive Officer; the REDD+ CBO leader, forest monitors, fire breakers as well as the District Natural Resources Officer (DNRO). There were eight key informants from whom information was obtained. Key informants were asked pre-determined questions and then allowed to respond. Their responses were guided by the researcher who was the moderator. Types of data collected using this method included socio-economic activities of villagers; awareness of causes of deforestation and forest degradation.

\subsubsection{Focus Group Discussions (FGDs)}

Focus group discussions were also used to collect qualitative data. The FGDs involved two processes, which were brainstorming and discussions. According to Pripathy \& Pripathy (2017), in a focus group discussion, a small number of individuals (e.g. 8 - 12) are brought together to talk about some topic of interest to a focus group moderator. There were four focus groups comprising 10 individuals each. The first group included farmers; the second one represented women as the major forest resource users; the third group consisted of businessmen; and the last focus group represented honey gatherers. The four focus groups were identified as the main forest resource users in the study area. The same types of data as those collected using semi-structured interviews such as socio-economic activities of villagers; awareness of causes of deforestation and forest degradation were obtained.

\subsubsection{Field observation}

In this study, unstructured observation was used to gather information on socio-economic activities such as logging/lumbering. Visits were made to different locations in the study area, such as village forest lands, Masito forest and within villages in the study area to observe socio-economic activities and development (Mulhall, 2003). Photographs were taken to illustrate the status of deforestation and forest degradation.

\subsection{Data Analysis}

The vector data obtained from the satellite imageries after classification of land 
cover and use types were used for analysis so as to identify changes using ArcGIS V10.1. Overlaying analysis was done by comparing land cover of 1990, 2000 and 2014 to identify the changes in land cover and use whereby the area of each land cover was computed to know the increase or decrease of a certain land cover. A land cover change detection matrix, as well as graphs using Microsoft Excel was generated for easy identification of changes.

Qualitative data, which involved those obtained using FGDs and semi-structured interviews, were analyzed using the content analysis approach (GAO, 1989; Stewart \& Shamdasani, 2017). Under the content analysis, materials to be analyzed were first determined. The next step involved categorization of the recorded units into several themes falling under the study objectives. Qualitative data collected using questionnaires were intended to generate outputs in terms of frequencies and percentages, which revealed perceptions of the respondents on particular matters. Quantitative data gathered using household questionnaires were analyzed using IBM Statistical Package for Social Sciences (SPSS), version 20.0. The first step in the analysis of quantitative data was preparation of variables followed by coding the responses in a code book and analysis of different variables (Stewart \& Shamdasani, 2017).

\section{Results and Discussion}

\subsection{Extent of Deforestation and Forest Degradation}

Majority of the respondents (79.2\%) agreed that deforestation and forest degradation had happened in the area; only few (20.8\%) reported that there was no deforestation or forest degradation. These findings are supported by results from satellite imagery interpretation (Figures 2-4; Table $2 \&$ Table 3), which show a decrease in closed woodland, dense bushland and bushed grassland and an increase in open woodland and cultivated land between 2000 and 2014. There is clear evidence of woodland degradation and deforestation, illustrated by the opening up of dense woodlands, and replacement of woodlands, bush lands, thickets and bushed grasslands by cultivated lands, respectively.

The patterns of land use and cover for 1990 (Figure $2 \&$ Table 2) reveal that during that time the dominant cover types in the study area were open woodland, closed woodland and open grassland. Cultivated land only covered a small area (2.23\%) while settlement area and forest had the least coverage. By 2000, closed woodland, open grassland and forest had decreased (Table 2 \& Figure 2). Closed woodland decreased by $11.1 \%$ (Table 3 ) indicating degradation of the woodland. Open grassland decreased to $11.88 \%$. Other cover categories that showed a decrease were dense bushland, bushed grassland and forest while cultivated land increased during the two time periods. On the other hand, open woodland and cultivated land increased during the same time period (Table 2 \& Figure 2). Open woodland had increased by $10 \%$ between 1990 and 2000 while cultivated land increased by $7.5 \%$ (Table 3 ).

The same pattern was observed in 2014 (Table 2 \& Figure 4). In actual fact the dominant cover types during this period had changed to open woodland and 


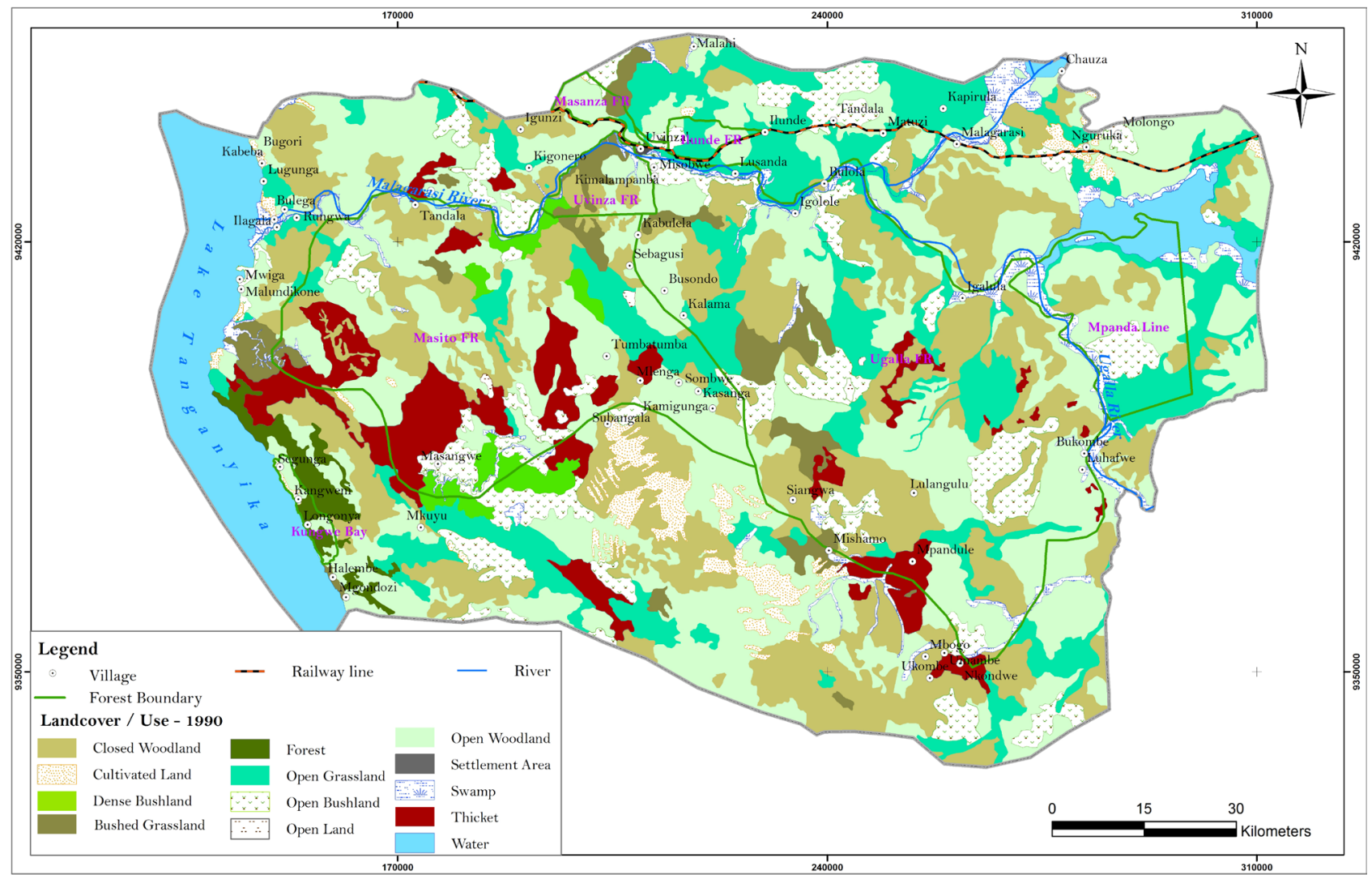

Figure 2. Land cover in Masito-Ugalla Ecosystem, 1990.

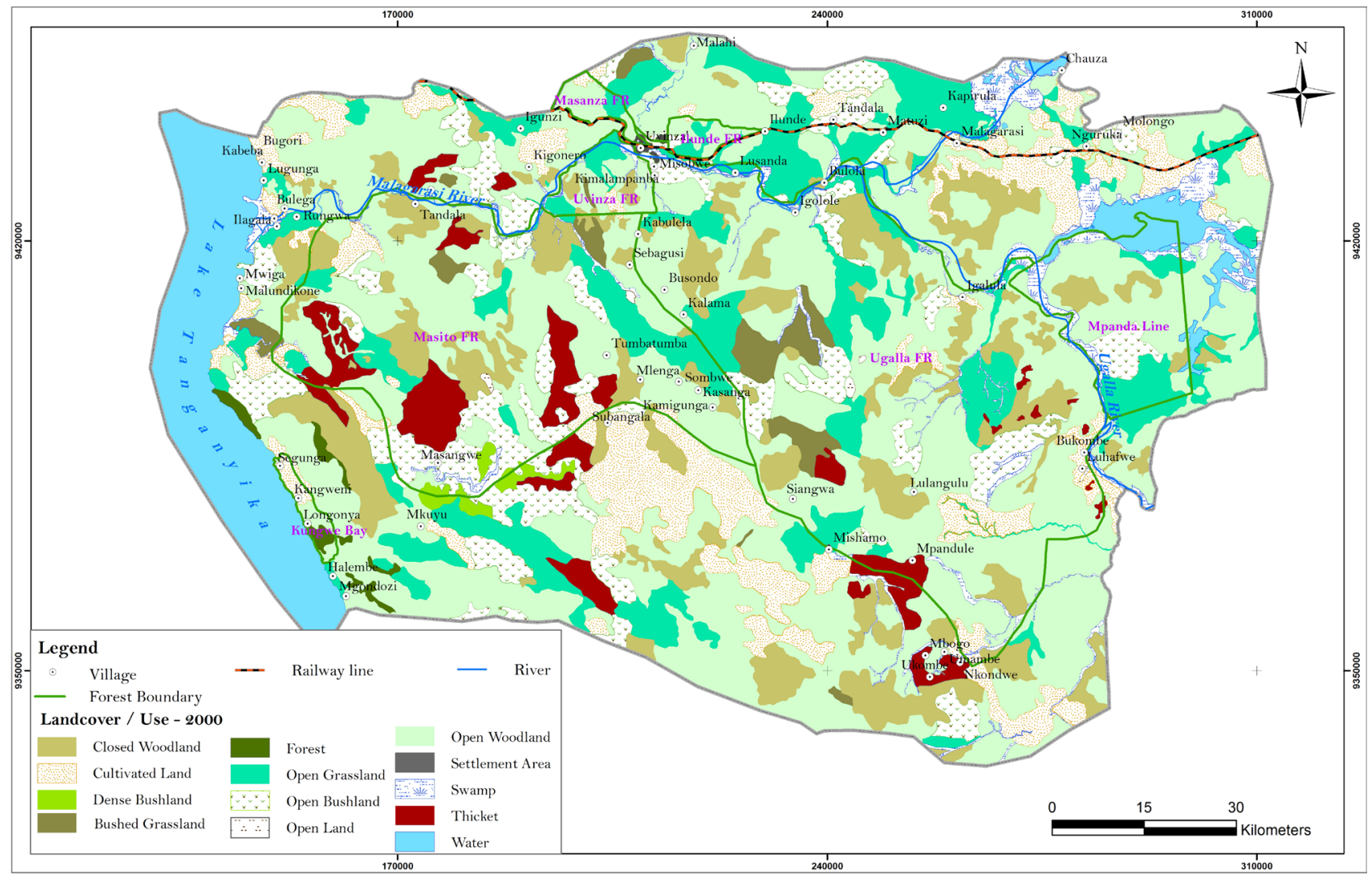

Figure 3. Land cover in Masito-Ugalla Ecosystem, 2000. 


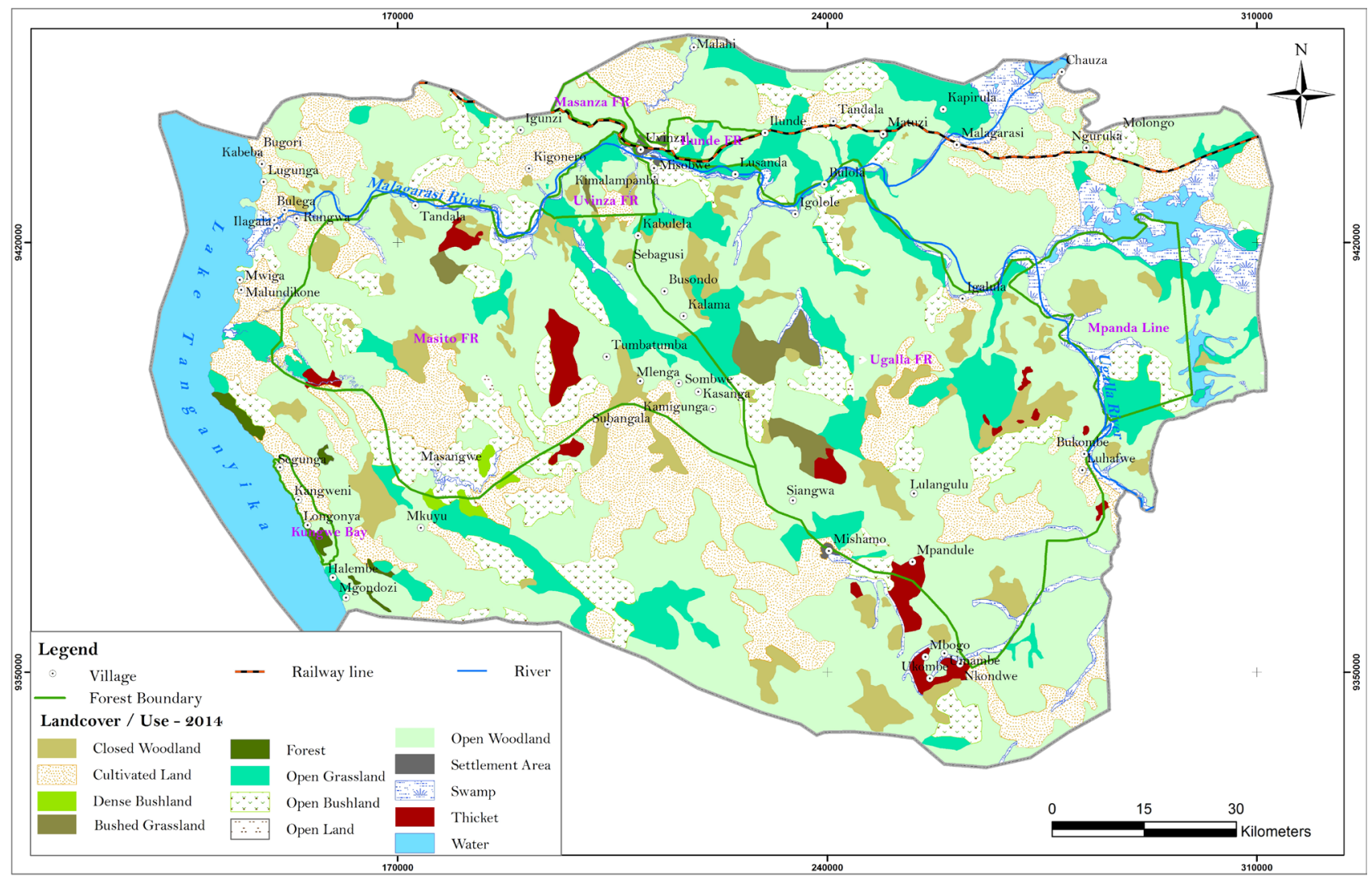

Figure 4. Land cover in Masito-Ugalla Ecosystem, 2014.

Table 2. Area coverage of land cover/use categories in Masito-Ugalla Ecosystem for 19902014.

\begin{tabular}{ccccccc}
\hline & \multicolumn{5}{c}{ Area coverage of land use/cover classes } \\
\cline { 2 - 7 } Land use/cover classes & \multicolumn{2}{c}{1990} & & \multicolumn{2}{c}{2000} & \multicolumn{2}{c}{2014} \\
& Ha & $\%$ & Ha & $\%$ & Ha & $\%$ \\
\cline { 2 - 7 } & 43,039 & 2.72 & 24,459 & 1.55 & 14,488 & 0.92 \\
Bushed grassland & 366,710 & 23.17 & 190,479 & 12.03 & 88,285 & 5.58 \\
Closed Woodland & 35,343 & 2.23 & 154,113 & 9.74 & 271,020 & 17.12 \\
Cultivated Land & 19,170 & 1.21 & 6443 & 0.41 & 3066 & 0.19 \\
Dense Bushland & 16,311 & 1.03 & 6165 & 0.39 & 4143 & 0.26 \\
Forest & 124,203 & 7.85 & 132,831 & 8.39 & 127,770 & 8.07 \\
Open Bushland & 226,897 & 14.34 & 188,078 & 11.88 & 152,627 & 9.64 \\
Open Grassland & 1386 & 0.09 & 1164 & 0.07 & 991 & 0.06 \\
Open Land & 489,896 & 30.95 & 648,858 & 41.00 & 721,863 & 45.61 \\
Open Woodland & 272 & 0.03 & 1247 & 0.08 & 1831 & 0.12 \\
Settlement Area & 47,681 & 3.01 & 51,240 & 3.24 & 59,483 & 3.76 \\
Swamp & 84,105 & 5.31 & 54,082 & 3.42 & 20,643 & 1.30 \\
Thicket & 127,542 & 8.06 & 123,596 & 7.81 & 116,545 & 7.36 \\
Water & $1,582,755$ & 100 & $1,582,755$ & 100 & $1,582,755$ & 100 \\
\hline Total & & & & & &
\end{tabular}


Table 3. The rate of change (in hectares and percent) of land use/cover classes for 19902014.

\begin{tabular}{|c|c|c|c|c|c|c|}
\hline \multirow{3}{*}{ Land use/cover classes } & \multicolumn{6}{|c|}{ Net cover change } \\
\hline & \multicolumn{4}{|c|}{$2000-2014$} & \multicolumn{2}{|c|}{$1990-2014$} \\
\hline & $\mathrm{Ha}$ & $\%$ & $\mathrm{Ha}$ & $\%$ & \multicolumn{2}{|c|}{$\mathrm{Ha} \quad \%$} \\
\hline Bushed grassland & $-18,580$ & -1.17 & -9971 & -0.63 & $-28,551$ & -1.8 \\
\hline Closed Woodland & $-17,6231$ & -11.13 & $-102,194$ & -6.46 & $-278,425$ & -17.59 \\
\hline Cultivated Land & 118,770 & 7.50 & 116,707 & 7.39 & 235,677 & 14.89 \\
\hline Dense Bushland & $-12,727$ & -0.80 & -3377 & -0.21 & $-16,104$ & -1.02 \\
\hline Forest & $-10,146$ & -0.64 & -2022 & -0.13 & $-12,168$ & 0.77 \\
\hline Open Bushland & 8628 & 0.55 & -5061 & -0.32 & 3567 & 0.22 \\
\hline Open Grassland & $-38,819$ & -2.55 & $-35,451$ & -2.24 & $-74,270$ & -4.7 \\
\hline Open Land & -222 & -0.01 & -173 & -0.01 & -395 & -0.03 \\
\hline Open Woodland & 158,962 & 10.04 & 73,005 & 4.61 & 231,967 & 14.66 \\
\hline Settlement Area & 775 & 0.05 & -584 & 0.04 & 1359 & 0.09 \\
\hline Swamp & 3559 & 0.22 & 8243 & 0.52 & 11,802 & 0.75 \\
\hline Thicket & $-30,023$ & -1.90 & $-33,439$ & -2.11 & $-63,462$ & -4.01 \\
\hline Water & -3946 & -0.25 & -7051 & -0.45 & $-10,997$ & -0.7 \\
\hline
\end{tabular}

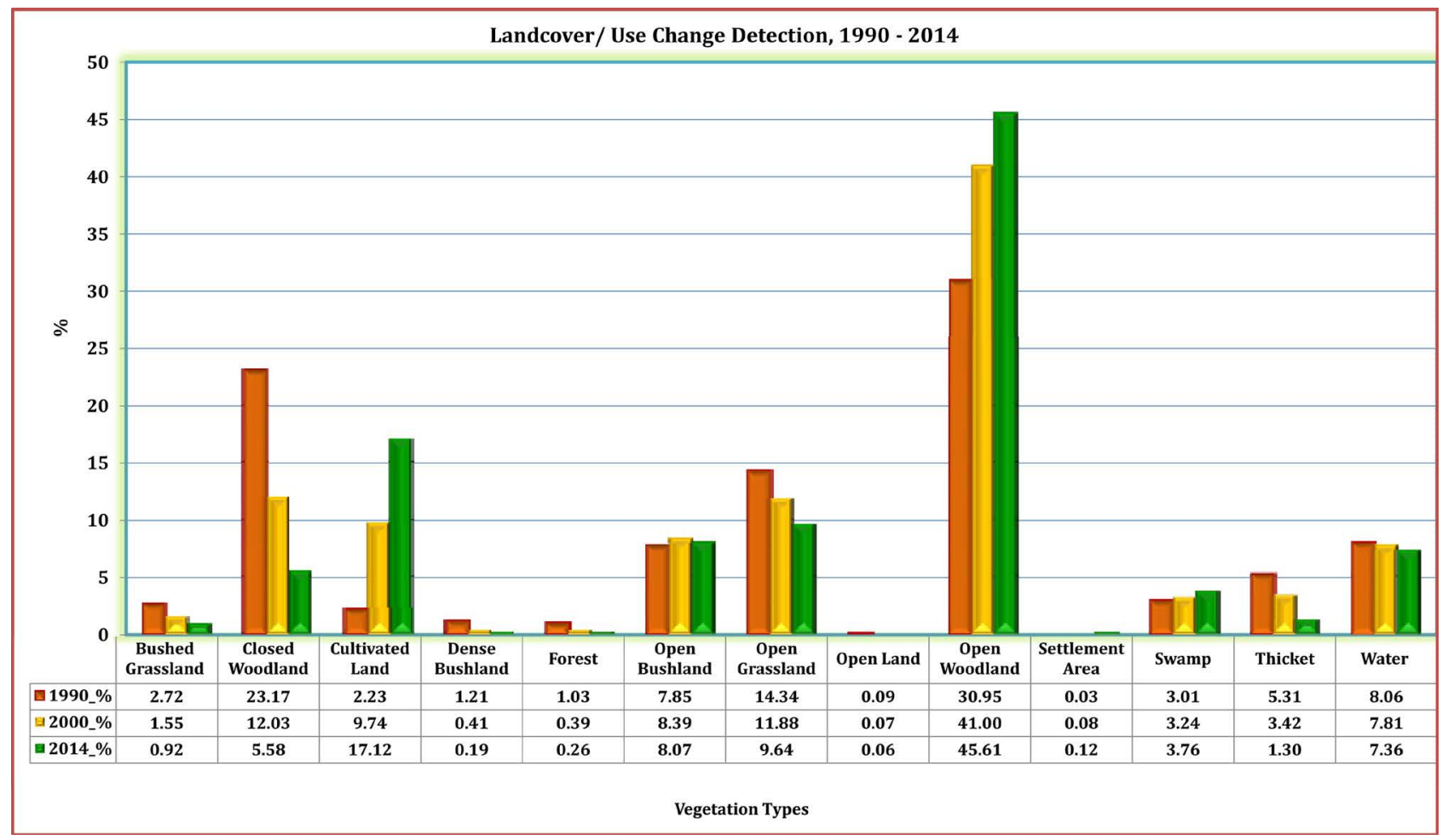

Figure 5. Visualization of land cover/use change in Masito-Ugalla Ecosystem for 1990-2014.

cultivated land. Closed woodland had diminished to only 5.6\% from $23.2 \%$ in 1990 (Table 2 \& Table 3) while cultivation increased to 17.12 in 2014 from $2.23 \%$ in 1990. This gives a clear indication of the extent of deforestation and woodland degradation, which may have resulted from anthropogenic activities. Figure 5 visualizes how the different land cover and use types had increased or 
decreased between 1990 and 2014 .

These findings were also supported by Plate $1 \&$ Plate 2, which illustrate tree felling in the study area and a typical deforested area, respectively. One of the key informants revealed that deforestation was an act, which did not necessarily require capital; it was just someone's effort and time. This means that everyone was free to engage in acts that would lead to deforestation and degradation.

The above findings supported the findings of other studies, which also reported the problem of deforestation in other parts of the world including some REDD+ project areas as explained below. For example, deforestation was reported by Su et al. (2011) to be a common phenomenon in Quezon Province, Philippines (The presence of deforestation at a rate of $2.4 \%$ in the Sofala Community Carbon Project, in Mozambique, between 1999 and 2007 was observed (Mori, 2013). Other REDD+ project areas that were reported to have been experiencing deforestation were the Rimba Raya Biodiversity Reserve REDD+ Project, in Indonesia, where $4.29 \%$ of the forest had been lost within a period of six years, from 2003 to 2008, and Bugondo-Bugoma Landscape REDD+ Project, in Hoina, Kibaale and Kyenjojo Districts, in Uganda, where 3.5\% of the forest,

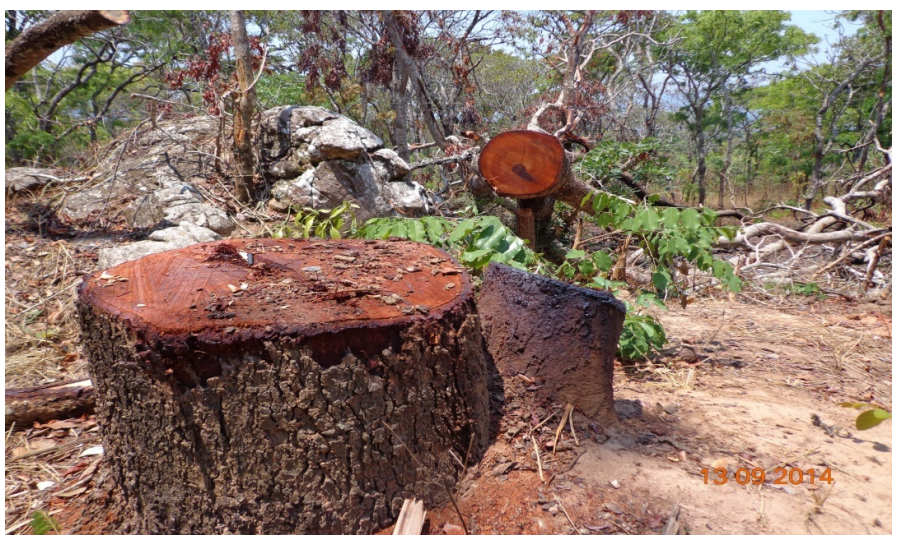

Plate 1. Tree felling in Masito forest, which is likely to degrade the forest.

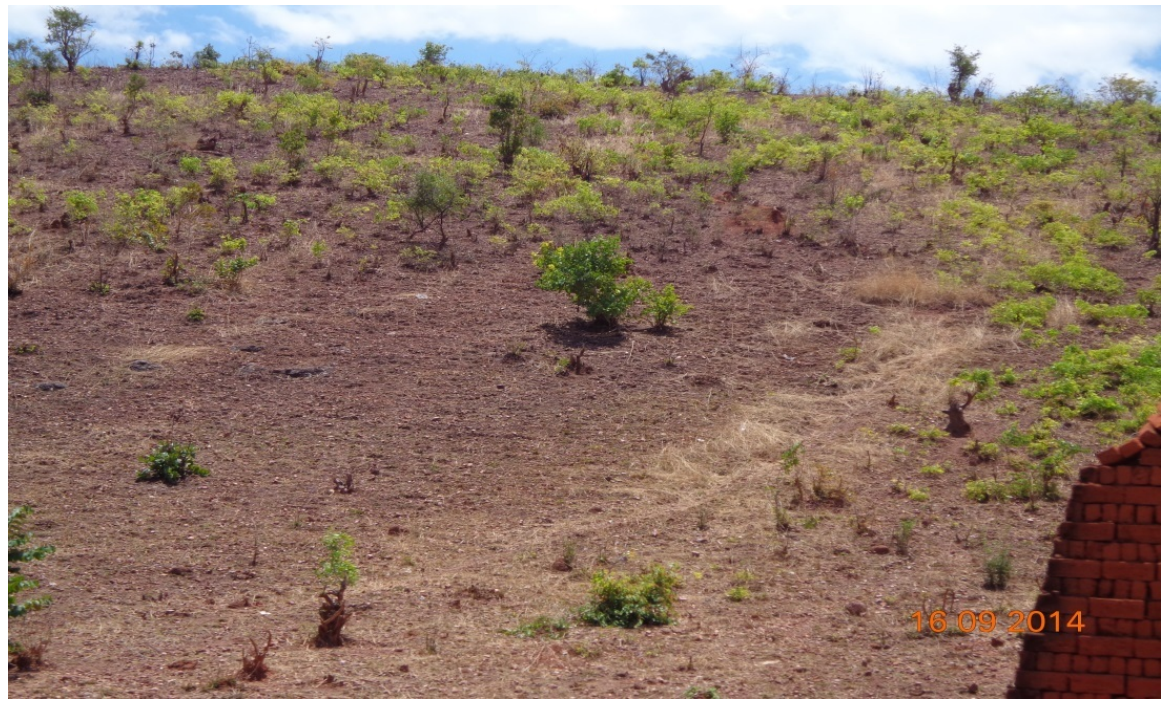

Plate 2. A typical deforested area at Ilagala village, Uvinza district. 
equal to 945 ha were lost due to deforestation during the first year of the project implementation (Mori, 2013).

Findings by Kashaigili et al. (2013) in Tanzania revealed that during the period 1980-1995 and 1995-2010, closed forest decreased by 635.5 ha $(-11.9 \%)$ and 1674.9 ha $(-31.3 \%)$, respectively. Similarly, in the period 1980-1995, settlement and other land uses increased by $85 \mathrm{ha}(1.6 \%)$ and 439.2 ha (8.2\%) between 1995 and 2010. During the period 1980-1995 closed forest decreased by 109.2 ha $(-4.5 \%)$ and 611.1 ha $(-25.3 \%)$ for the period 1995-2010. On the contrary, in the period 1980-1995, settlement and other land uses increased by 75 ha (3.1\%) and 100.2 ha (4.1\%) between 1995 and 2010. According to them, while closed forest decreased between 1980 and 2010, bushland, grassland, settlement and other land uses, and Open Forest increased.

Hansen \& De Fries (2004), who examined the long term change of global forest cover using Advanced Very High Resolution Radiometer (AVHRR), observed that the tree cover of the world had decreased between 1984 and 1997 and the annual deforestation rate in tropical Africa was about $0.09 \%$. In his study to identify and map deforestation using Landsat images and Global Inventory Modeling and Mapping Studies (GIMMS) data from 1980s to 2000s, Wu (2011) found that Kenya still remained at a deforestation rate of about $0.3 \%$ per year. Large loss of forest area was indicated for Tanzania and Uganda, about $1.2 \%$ and $2.7 \%$ per year, respectively.

\subsection{Causes of Deforestation and Forest Degradation}

Factors that enhance deforestation and forest degradation fall into three categories namely: proximate causes, underlying causes and other factors. Proximate factors include agricultural expansion, wood extraction, and infrastructure extension while the underlying causes are demographic, economic, technological, policy and institutional as well as cultural or socio-political factors (Madeira, 2008; Abdullah \& Mahmud, 2005; Geist \& Lambin, 2002). Other factors include pre-disposing environmental factors, such as land characteristics like soil quality and topography; biophysical factors such as wildfires and pest; and socio trigger events such as wars/ civil strife and sudden displacement. In this study, the causes that were identified could also be grouped into proximate, underlying and other factors (Madeira, 2008; Abdullah \& Mahmud, 2005).

\subsubsection{Proximate Causes}

The proximate causes of deforestation and woodland degradation are presented in Table 4. The demand for forest products and land for cultivation and settlement, among other needs, were the major factors accelerating the loss of forest ecosystems in the study area. Uncontrolled farming was reported by the majority of the respondents as the dominant factor for deforestation and forest degradation. This is in line with the findings presented in Table $2 \&$ Table 3, which show a tremendous increase of cultivated land between 1990 and 2014. Other factors mentioned were uncontrolled encroachment, illegal logging/lumbering and illegal honey gathering. 
Table 4. Causes of deforestation and forest degradation in Masito-Ugalla Ecosystem.

\begin{tabular}{ccc}
\hline Factors & Frequency of responses $(\mathrm{N}=101)$ & Percent of Respondents \\
\hline Uncontrolled Encroachment & 22 & 21.8 \\
Uncontrolled Farming & 31 & 30.7 \\
Illegal Logging/Lumbering & 16 & 15.8 \\
Illegal Honey Gathering & 12 & 11.9 \\
Poor Institutional Framework & 19 & 18.8 \\
No response & 1 & 1.0 \\
Total & 101 & 100.0 \\
\hline
\end{tabular}

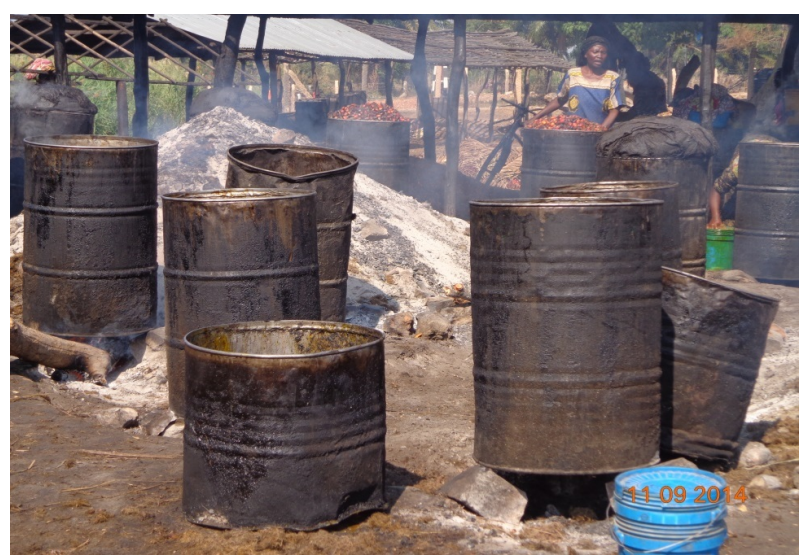

Plate 3. Traditional processing of oil from palm kernels at Ilagala village.

It was reported during the focus group discussions and key informant interviews that there were incidences of encroachment in natural forests, especially in village forests, made purposely for clearing and expanding farm lands as well as obtaining fuel wood. Field observations showed that oil processing from palm kernels (Plate 3) and burnt bricks making were among the activities, which demanded large amounts of fuel-wood. It was also observed that traditionally, drying fish in villages surrounding Lake Tanganyika was done using fuel-wood. Therefore, the expansion of markets for fish within and beyond Kigoma region would thus require huge amounts of firewood to meet the demands. Rural areas within Masito-Ugalla ecosystem are used as exit points for charcoal, which is transported using Sigunga-Ilagala road to Kigoma urban.

The above findings were in line with findings from other studies such as Hogqvist et al. (1998); Ahrends (2005); Malugu (2007); Svoboda \& McNamara (2009); Su et al. (2011). For example, Svoboda \& McNamara (2009) reported that deforestation in the Masito-Ugalla ecosystem was due to the increase in human practices such as farming, cutting down trees for charcoal burning and fuelwood (). While public forests and village lands were commonly used for fuel wood, lack of reforestation activities were leaving open areas forcing some people to illegally obtain resources from nearby forest reserves. Random re- 
peated burning was also reported to be the biggest impediment to forest maintenance and regeneration (Svoboda \& McNamara, 2009).

Some of the human activities that contributed to the degradation of the forest reserves in Tanzania include charcoal burning, logging, encroachment for agriculture and pole cutting and expansion of farms within the forest reserves (Hogqvist et al., 1998; Ahrends, 2005; Malugu, 2007). Similarly, Su et al. (2011) revealed that in Quezon Province, in Philippines, the problem of deforestation emanated from illegal logging, excessive faming and conversion of forests to agricultural lands as well as conversion of forests to urban settlements ().

\subsubsection{Underlying Causes}

This subsection discusses a number of underlying causes of deforestation in the study area. They include: demographic factors, socio-economic factors, political and institutional factors and technological and biophysical factors.

\section{1) Demographic factors}

Population increase was found to be among the underlying factors augmenting deforestation in the study area. Gauging from the high population growth rates in other districts, there is no doubt that Uvinza district has experienced a similar pattern of population increase, with negative impacts on forests. It was observed in the study area that, majority of the villagers were living a low life standard, which made them dependent on forest resource as a means of attaining livelihood, thereby, affecting the resource. Because of rapid population growth (Kumar et al., 2010) among other reasons, in Kodagu District, Southern India, more than 200 hectares of forest in the region had been encroached since 1990 onwards.

The size of households has a bearing on deforestation and forest degradation. The larger the household size the higher the demand for land for cultivation to meet the food needs as well as the demand for forest products. Findings from the household interviews revealed a big number of household members in the study area. About half of the households (50.5\%) had household size ranging from 6 to above 9 members. Out of these, $27.7 \%$ had 6 - 9 members while $22.8 \%$ had above 9 members. An additional $43.6 \%$ of the households had 2-5 members, the mean and standard deviation being 2.67 and .89, respectively, and only very few (5.9\%) had a single member. This study examined reasons for the high household size in the study area. It was noted that habitually, many adult males in the study area preferred polygamous marriages, which have higher chances of increasing the number of children in a single household.

\section{2) Socio-economic factors}

Local social and economic factors such as poverty, poor education and lack of employment were found to impinge on efforts to conserve forest resources in the study area. Respondents' income was found to be very low. Majority of the respondent (68.3\%) had a monthly income level below TZS. 40,000 $\neq$ and very few (5.9\%) earned between TZS. 201,000 $\neq$ and 300,000 $\neq$. The highest income group consisted of government employees and those engaged in small businesses. Generally, females were found to have less income than males. However, there 
was no statistically significant difference in the monthly income between males and females: $\mathrm{t}(99)=1.056, p=0.293)$. The magnitude of the differences in the means was very small, with males having a slightly higher income than females (the eta squared statistics was 0.011).

It was observed that majority of the villagers were farmers who depended on selling their agricultural products. They also lacked reliable income generating activities, which would supplement their monthly income. This situation suggests extreme income poverty in the study area, a factor which indicates overexploitation of forest resources in the absence of alternative livelihood options. Some key informants mentioned higher rates of poverty and limited employment opportunities in the study area as potential causes of deforestation. One of the key informants said that poverty increased the rate of deforestation and forest degradation in the study area due to increased demand for wood-fuel for palm oil processing and other domestic uses.

The above findings are supported by Klein (2002) and Ngalason (2009) who found that people in Uvinza District had the lowest per capita income, as low as $\$ 150$ per year, which was among the factors contributing to the excessive pressure on the utilization of natural resources. Kigoma was among the regions in the country with low rates of literacy and school completion, thus impinging on majority of the people to access employment, all of which contribute to the extreme pressure on natural resources (Ngalason, 2009).

\section{3) Political and institutional factors}

Poor natural resources governance was among the hurdles limiting the success in conserving forests and their associated biological diversity in the study area. Factors like corruption and embezzlement of funds impinged the performance of the REDD+ project. These factors had detrimental consequences, accelerating the violation of natural resource conservation laws among others. It was also reported by majority of the respondents that they had no title deeds for the land they owned and only $2 \%$ agreed that they had a title deed. When asked about the reasons for not owning land, fifty percent of the respondents reported that they were not owning land due to lack of knowledge in interpreting the Village Land Act, while the other $50 \%$ of the respondents said that accessing land in their area was expensive.

The close proximity of the refugee camps to the forest reserves has also been a key contributing factor to environmental degradation and deforestation. Both refugees and locals continued to encroach upon the forest reserves, primarily to collect firewood or wood for construction, or to clear areas for cultivation (UNEP \& CBD, 2001; Relief, 2003). Deforestation and depletion of forest resources (Relief, 2003) were the most often-cited environmental problem in Western Tanzania, the rate of deforestation being reportedly higher than the national average. Deforestation was most apparent when the areas outside of the refugee camps were contrasted with those within the camp boundaries, because unlike the village and forestlands, the lands within the camp boundaries were fairly being well patrolled. The major causes of refugees' influx were political and 
institutional factors (TRAFFIC, 2006).

The above findings support the findings of other scholars such as (Madeira, 2008; Svoboda \& McNamara 2009; Burgess et al., 2012; NORAD, 2013). Weak governance institutions and corruption were associated with illegal logging in parts of Asia and with agricultural expansion in Latin America (Madeira, 2008). In the Democratic Republic of Congo (DRC), a number of politicians, including those in the government circles and Parliament, as well as high-ranking civil servants allegedly engaged in industrial and artisanal logging (NORAD, 2013). It has also been well established that military operations caused deforestation in Vietnam during the Vietnam War and elsewhere (Sands, 2005). The role of military in deforestation has also been documented in Southeast Asia and South America (Mather, 1991; Sands, 2005).

\section{4) Technological factors}

Technological factors have contributed to acceleration of forest degradation and deforestation in the Masito-Ugalla ecosystem. This is due to industrial activities that demand fuel-wood, thus causing negative consequences on forest conservation. A good example is the Uvinza Salt Mine, which was allegedly utilizing 20,000 cubic meters of fuel-wood per day for drying ovens (Svoboda \& McNamara, 2009).

\section{5) Biophysical drivers}

Unplanned wildfires are among the environmental problems facing the study area. During the study several fire incidences were observed in Masito forest (Plate 4). One key informant explained that wildfires in Masito-Ugalla ecosystem were largely contributed by unsustainable farming activities. Fires were being used to help clear land for farming, re-juvenate rangeland grasses, and were sometimes due to cultural norms. Sometimes hunters and honey gatherers also used fire to attract animals during growth of new pastures and as a traditional honey collection method, respectively, all of which posed negative impacts on forest resources.

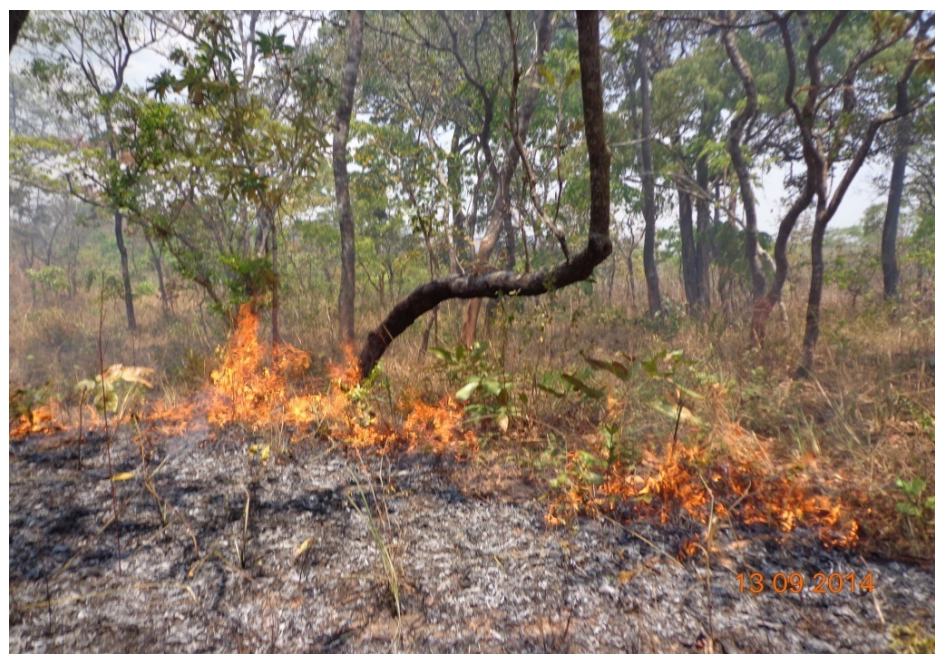

Plate 4. Unplanned wildfire in Masito forest, such fire is likely to cause tremendous negative impacts to the ecosystem. 
According to research findings (Svoboda \& McNamara, 2009) recent and active fires were observed throughout the Masito-Ugalla ecosystem. Accordingly, the combined effects of fire and drought destroyed $25,500 \mathrm{~km}^{2}$ of primary and secondary forest and a further $7500 \mathrm{~km}^{2}$ of settlement areas in previous years before the project was initiated. The misuse and over-use of fire as a cheap method of land clearing had also caused massive changes to the vegetation of large areas in Indonesia (Murdiyarso \& Adiningsih, 2003). It has also been found that fire poses the greatest threat to Amazon forests (Cochrane \& Laurance, 2002).

Apart from fire, there is an interrelationship between climate warming, drought and loss of vegetation cover. Drought can be characterized as a deviation from normal conditions in the physical system such as climate and hydrology (Lanen et al., 2007). As a result of drought many forests are threatened by secondary effects of climate change, such as a potential increase in the frequency and possibly intensity of fires (Lanen et al., 2007).

Although it has been difficult to attribute changes in forests and woodlands to climate change because of the interactions between natural climate variability, anthropogenic climate change and human induced land use change (IPCC, 2014) there are evidences that associate such changes to climate change. In the Amazon forest, for example, a link between forest fires, habitat fragmentation, climate change, and extreme El Niño events has been well established (Cochrane \& Laurance, 2002). Sanderson et al. (2010), also observed that in all forest types, a warming climate could promote the frequency and severity of pest outbreaks, which will damage the health of the forest and may reduce the numbers of certain species. They further observed that reduced precipitation could negatively affect agricultural yields and other economic activities which majority of the people depend up on, thus forcing them to go to forests where they might lead to deforestation and forest degradation for the purpose of earning a living. Long term declines in density of trees and shrubs in the Sahel zone of Senegal have also been attributed to drought stress induced by decreased precipitation (IPCC, 2014). All in all, the IPCC (2014) reports of the general consensus that future changes in terrestrial ecosystems throughout Africa will likely be driven by continued changes in precipitation and carbon dioxide associated with climate change.

\subsection{Measures for Minimizing Deforestation and Forest Degradation}

When respondents were asked about measures that needed to be taken to minimize deforestation and degradation, $45.5 \%$ recommended environmental conservation education as the best measure. Effective law enforcement was reported by $18.8 \%$ and $15.5 \%$ of the respondents mentioned the provision of land tenure rights as the appropriate measure. Only very few (8.9\%) mentioned capacity building on non-farm activities and controlling corruption in the forestry sector (10.9\%). Environmental conservation education was seen as a reliable measure because it has been commonly used to deliver conservation message among local communities. 
A Chi-square test of respondents' education level and measures to minimize deforestation and forest degradation revealed that the relationship between the two variables was statistically significant $\left[\chi^{2}(12, \mathrm{~N}=101)=23.24, p>0.026\right]$. This meant that respondents' knowledge and skills in natural resources management were of paramount importance in understanding suitable measures needed for minimizing deforestation and forest degradation in the study area.

\section{Conclusion}

From the preceding discussion, it may be concluded that deforestation and forest degradation was a big problem within forest reserves as well as village lands in the Masito-Ugalla ecosystem. Findings generated through analysis of satellite data indicated a diminished closed woodland, open grassland, bushed grassland, forest and thickets between 1990 and 2014. On the contrary, settlement area, cultivated land and open woodland had increased in the same time frame. Major factors causing deforestation and forest degradation were uncontrolled farming, uncontrolled encroachment for farm lands and fuel-wood and illegal logging. Providing effective environmental conservation education and alternative sources of energy would to a large extent minimize the problem. Further, effective law enforcement and increased patrols will ultimately reduce chances of people to encroach in the forests, thereby, increasing effectiveness in conserving the Masito-Ugalla ecosystem.

\section{Conflict of Interest}

Authors declare no conflict of interest.

\section{References}

Abdullah, S. M. S., \& Mahmud, M. (2005). Tropical Deforestation and Its Impacts on Environment and Quality of Life.

http://www.apn-gcr.org/images/programmesAndActivities/HyogoActivities/Hyogo5/H yogo5_Mastura_Mahmud.pdf

Ahrends, A. (2005). Patterns of Degradation in Lowland Coastal Forests in Coast Region, Tanzania. MSc Thesis, Greifswald: Greifswald University.

Baboo, S., \& Devi, M. R. (2011). Geometric Correction in Recent High Resolution Satellite Imagery: A Case Study in Coimbatore, Tamil Nadu. International Journal of Computer Applications, 14, 32-37. https://doi.org/10.5120/1808-2324

Bolton, R. N. (1993). Pretesting Questionnaires: Content Analyses of Respondents' Concurrent Verbal Protocols. Marketing Science, 12, 280-303. https://doi.org/10.1287/mksc.12.3.280

Burgess, R., Hansen, M., Olken, B., Potapov, P., \& Sieber, S. (2012). Corruption and REDD + Identifying Risks amid Complexity.

Caelli, T., \& Reye, D. (1993). On the Classification of Image Regions by Color, Texture and Shape. Pattern Recognition, 26, 461-470.

CIFOR (2014). Chapter 12: Building REDD Readiness in the Masito Ugalla Ecosystem Pilot Area in Support of Tanzania's National REDD Strategy. http://www.cifor.org/redd-case-book/case-reports/tanzania/

Cochrane, M. A., \& Laurance, W. F. (2002). Fire as a Large-Scale Edge Effect in Amazo- 
nian Forests. Journal of Tropical Ecology, 18, 311-325.

https://doi.org/10.1017/S0266467402002237

Deloitte (2012). Mid-Term Review Report of Nine NGO REDD + Pilot Projects in Tanzania. http://www.norway.go.tz/

FAO (2009). Towards Defining Degradation by Markku Simula (p. 11). FRA Working Paper 154, Rome: FAO.

FAO (2010). Global Forest Resources Assessment 2010-Main Report. Forestry Paper No. 163, Rome: FAO.

FAO (2011). Economic and Social Significance of Forests for Africa's Sustainable Development. Nature and Faune, 25.

FAO (2016). State of the World Forests. Rome: FAO. http://www.fao.org/publications/sofo/2016/en/

GAO (General Accounting Office) (1989). Content Analysis: A Methodology for Structuring and Analyzing Written Material. Washington DC: GAO. http://archive.gao.gov/d48t13/138426.pdf

Geist, H. J., \& Lambin, E. F. (2002). Proximate Causes and Underlying Driving Forces of Tropical Deforestation. BioScience, 52, 143-150. https://doi.org/10.1641/0006-3568(2002)052[0143:PCAUDF]2.0.CO;2

Hansen, M. C., \& DeFries, R. S. (2004). Detecting Long-Term Global Forest Change using Continuous Fields of Tree-Cover Maps from 8-km Advanced Very High Resolution Radiometer (AVHRR) Data for the Years 1982-99. Ecosystems, 7, 695-716. https://doi.org/10.1007/s10021-004-0243-3

Hogqvist, M., Nummelin, S., Stahl, M., \& Miljoventen-skap, B. (1998). The View of Nature of Villagers in Kisarawe District. Karlstad: The Department of Nature and Environment, Karlstad University.

Hosonuma, N., Herold, M., De Sy, V., De Fries, R. S., Brockhaus, M., Verchot, L., Angelsen, A., \& Romijn, E. (2012). An Assessment of Deforestation and Forest Degradation Drivers in Developing Countries. Environmental Research Letters, 7, 4009. https://doi.org/10.1088/1748-9326/7/4/044009

IPCC (2014). Climate Change 2014 Impacts, Adaptation, and Vulnerability: Summaries, Frequently Asked Questions, and Cross-Chapter Boxes. A Working Group II Contribution to the Fifth Assessment Report of the Intergovernmental Panel on Climate Change.

https://www.ipcc.ch/pdf/assessment-report/ar5/wg2/WGIIAR5-IntegrationBrochure_F INAL.pdf

Johnson, R. L., \& Chenje, M. (2008). Africa: Atlas of Our Changing Environment. Nairobi: United Nations Environment Programme (UNEP).

Kashaigili, J. J., Mdemu, M. V., Nduganda, A. R., \& Mbilinyi, B. P. (2013). Integrated Assessment of Forest Cover Change and Above-Ground Carbon Stock in Pugu and Kazimzumbwi Forest Reserves, Tanzania. Advances in Remote Sensing, 2, 1-9. https://doi.org/10.4236/ars.2013.21001

Klein, J. (2002). Deforestation in the Madagascar Highlands-Established "Truth" and Scientific Uncertainty. Geo Journal, 56, 191-199. https://doi.org/10.1023/A:1025187422687

Kumar, G. R. P., Hemanjali, A. M., Ravikumar, P., Somashekar, R. K., \& Nagaraja, B. C. (2010). Assessing the Historical Forest Encroachment of Kodagu Region of Western Ghats, South India using Remote Sensing and GIS.

https://www.nrsc.gov.in/sites/all/pdf/pram.pdf

Lanen, H. A. J., Tallaksen, L. M., \& Rees, G., (2007). Droughts and Climate Change. 
http://www.geo.uio.no/edc/downloads/droughts_and_climate_change_2007.pdf

Madeira, C. E. (2008). Policies to Reduce Emissions from Deforestation and Degradation $(R E D D)$ in Developing Countries: An Examination of the Issues Facing the Incorporation of REDD into Market-based Climate Policies.

http://www.rff.org/files/sharepoint/WorkImages/Download/RFF-Rpt-REDD_final.2.20 .09.pdf

Malugu, I. O. E. (2007). Resources-Use Conflicts and Management Challenges for Pugu and Kazimzumbwi Forest Re-Serves in Kisarawe and Ilala Districts, Tanzania. Discovery and Innovation, 19, 149-174. https://doi.org/10.4314/dai.v19i1-2.15781

Mather, A. S. (1991). Global Forest Resources. Dehra Dun: International Book Distributors.

Misana, S. B., \& Nyaki, F. R. (1993). Population and Deforestation in Tanzania. In D. Salaam, \& United Nations, Population, Environment and Development in Tanzania (pp. 41-60). New York, NY: United Nations.

Mori, H. (2013). Review of Selected REDD + Project Designs.

https://pub.iges.or.jp/system/files/publication_documents/pub/policyreport/3496/Book let_09-04-2013.pdf

Mulhall, A. (2003). Methodological Issues in Nursing Research in the Field: Notes on Observation in Qualitative Research. Journal of Advanced Nursing, 41, 306-313. https://doi.org/10.1046/j.1365-2648.2003.02514.x

Murdiyarso, D., \& Adiningsih, E. S. (2003). Causes of Indonesian Vegetation/Land Fires and Terrestrial Carbon Emissions.

http://www.fire.uni-freiburg.de/summit-2003/3-IWFC/Papers/3-IWFC-109-Murdivars o.pdf

Ngalason, P. (2009). Building REDD Readiness in the Masito-Ugalla Ecosystem Pilot Area in Support of Tanzania's National REDD Strategy. http://www.norway.go.tz/

NORAD (2013). Implementing REDD+ in the Democratic Republic of Congo How to Manage the Risk of Corruption. A Report Commissioned by NORAD Prepared by PricewaterhouseCoopers $\left(P_{W} C\right)$ in Collaboration with NORAD and UNDP.

http://www.redd-monitor.org/wp-content/uploads/2012/01/NORAD-PwC-Implementi ng-REDD-in-DRC-Corruption-risks-NORAD-Final-Version-E.pdf

Pickering, U., \& Owen, G. (1997). Impact of Deforestation on Environment. New York, NY: Herper and Row Publications.

Pripathy, P., \& Pripathy, K. P. (2017). Fundamentals of Research: Dissective View. https://books.google.com/books?isbn=3954894173

Reed, D. (1996). Structural Adjustment, the Environment, and Sustainable Development. London: Earthscan.

Relief (2003). Report on Buyungu Forest Reserve. Kibondo: REDESO Kibondo Office.

Rocchini, D., \& Rita, A. D. (2005). Relief Effects on Aerial Photos Geometric Correction. Applied Geography, 25, 159-168.

Sanderson, M., Santini, M., Valentini, R., \& Pope, E. (2010). Relationships between Forests and Weather. EC Directorate General of the Environment. http://ec.europa.eu/environment/forests/pdf/EU_Forests_annex1.pdf

Sands, R. (2005). Forestry in a Global Context. Wallingford: CABI Publishing.

Sitarz, D. (1994). Agenda 21: The Earth Summit Strategy to Save Our Planet. Boulder: Earthpress.

Stewart, D. W., \& Shamdasani, P. (2017). Online Focus Groups. Journal of Advertising, 46, 48-60. https://doi.org/10.1080/00913367.2016.1252288 
Su, G. S., Macawile, J., Villarino, A., Agapito, J., \& Gomez, N. (2011). Recognizing Local People's Perceptions towards Deforestation in Quezon Province, Philippines. Environmental Research Journal, 5, 131-135. https://doi.org/10.3923/erj.2011.131.135

Svoboda, D., \& McNamara, M. (2009). USDA Forest Service Technical Assistance Trip Watershed Assessment of the Masito-Ugalla Landscape.

https://rmportal.net/library/content/usda-forest-service/africa/usfs-watershed-assessm ent-of-the-masito-ugalla-landscape-1/at_download/file

TFWG (2009). Recommendations for the National Strategy on Reduced Emissions from Deforestation and Forest Degradation (REDD).

http://www.tfcg.org/pdf/Brief\%201\%20Recommendations\%20on\%20REDD\%20Strateg y_final.pdf

Timberlake, L. (1991). Africa in Crisis: The Causes, the Cures of Environmental Bankruptcy (2nd ed.). London: Earthscan.

TRAFFIC (2006). Anti-Poaching Conference, 17 October 2006.

UNEP and CBD (2001). Main Theme: Forest Biological Diversity. https://www.cbd.int/doc/meetings/sbstta/sbstta-07/information/sbstta-07-inf-03-en.pdf

URT (2014). Lake Tanganyika Integrated Regional Development Programme (PRODAP): Exit Strategy (Draft). http://www.vpo.go.tz/

Vicente-Serrano, S. M., Pérez-Cabello, F., \& Lasanta, T. (2008). Assessment of Radiometric Correction Techniques in Analyzing Vegetation Variability and Change Using Time Series of Landsat Images. Remote Sensing of Environment, 112, 3916-3934.

Wu, Y. (2011). Investigation of Deforestation in East Africa on Regional Scales. Master's Thesis Geography, 30 HECs, Stockholm: Stockholm University.

WWF (2016). Importance of Forests.

http://wwf.panda.org/about_our_earth/deforestation/importance_forests/

Submit or recommend next manuscript to SCIRP and we will provide best service for you:

Accepting pre-submission inquiries through Email, Facebook, LinkedIn, Twitter, etc. A wide selection of journals (inclusive of 9 subjects, more than 200 journals)

Providing 24-hour high-quality service

User-friendly online submission system

Fair and swift peer-review system

Efficient typesetting and proofreading procedure

Display of the result of downloads and visits, as well as the number of cited articles

Maximum dissemination of your research work

Submit your manuscript at: http://papersubmission.scirp.org/

Or contact ojf@scirp.org 